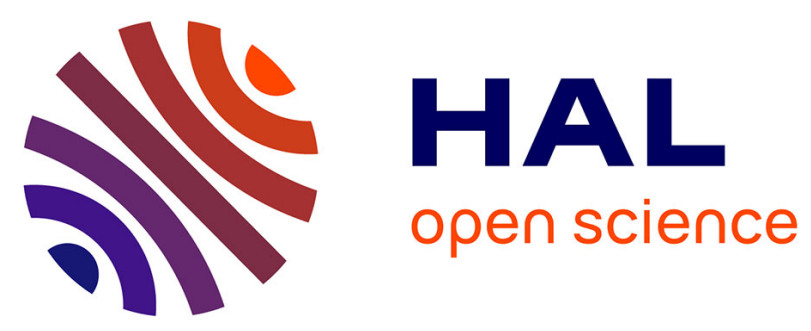

\title{
Response to Tomenson's letter on 'Lung cancer mortality in the French cohort of titanium dioxide workers: some aetiological insights'
}

Irina Guseva Canu, Danièle Luce, Kurt Straif

\section{- To cite this version:}

Irina Guseva Canu, Danièle Luce, Kurt Straif. Response to Tomenson's letter on 'Lung cancer mortality in the French cohort of titanium dioxide workers: some aetiological insights'. Occupational and Environmental Medicine, 2021, 78 (4), pp.304-304. 10.1136/oemed-2021-107420 . hal-03169691

\section{HAL Id: hal-03169691 https://hal.science/hal-03169691}

Submitted on 10 Jun 2021

HAL is a multi-disciplinary open access archive for the deposit and dissemination of scientific research documents, whether they are published or not. The documents may come from teaching and research institutions in France or abroad, or from public or private research centers.
L'archive ouverte pluridisciplinaire HAL, est destinée au dépôt et à la diffusion de documents scientifiques de niveau recherche, publiés ou non, émanant des établissements d'enseignement et de recherche français ou étrangers, des laboratoires publics ou privés. 


\title{
Response to Tomenson's comment on the Short report by Guseva Canu et al. Lung cancer mortality in the French cohort of titanium dioxide workers: some aetiological insights.
}

Guseva Canu Irina $^{1}$, Luce Daniele ${ }^{2,3}$, and Straif Kurt ${ }^{4}$

\author{
${ }^{1}$ Department of Occupational and Environmental Health, Center for Primary Care and \\ Public Health (Unisanté), University of Lausanne, Epalinges-Lausanne, Switzerland \\ ${ }^{2}$ IRSET, Rennes, Bretagne, France \\ ${ }^{3}$ University of Rennes 1 - Health Sciences Campus Villejean, Rennes, Bretagne, France \\ ${ }^{4}$ ISGlobal, Barcelona, Spain and Boston College, USA
}

We thank the editor for the giving us the opportunity to respond to the points raised by Tomenson. Further, we would like to thank Tomenson for making publicly available parts of the so far unpublished report to the sponsors (the Titanium Dioxide Manufacturers Association, for which he provides consultancy services), including particularly the positive dose-response data for the French sub-cohort (re-analysed in our paper). ${ }^{1}$

As clearly described in Methods and in Results of our short report, the cumulative exposure to TiO2 was lagged by 10 years. Obviously, this also affects the number of unexposed and exposed workers as reported in the supplemental Table S3. ${ }^{2}$ We recognize that we should have specified this also in the footnotes of that table.

Regarding tobacco smoking, data were available for 201 (not only 33) workers at the second French plant and the combined crude smoking prevalence for the two French plants was 34\%, compatible with the age-standardized prevalence of $42 \%$ reported by Boffetta et al. ${ }^{1}$ As discussed in our paper, ${ }^{2}$ we recognize that the reported prevalence of smoking was low, and lower than that estimated on the national level.

\section{ACCEPTED MANUSCRIPT}


As one part of our re-analysis, we used the available smoking data to explore potential confounding via multiple imputation for missing data, though we had to assume that data were missing at random. Given the relatively small number of cases, a complete case analysis (as suggested by Tomenson) would be much less informative.

In our re-analysis we found no evidence for confounding by smoking. Further, indirect methods support the notion that the observed positive dose-response relationship cannot be entirely explained by confounding due to smoking. ${ }^{3}$

Finally, we do not think that the increased risk among workers exposed to $\mathrm{TiO} 2$ or the positive dose-response relationship would be due to a low mortality rate in the unexposed workers. Using the low exposure group as reference would still result in the same pattern and in an increased risk in the highest exposure group. We note that a dose-response relationship was also apparent in the original report from Boffetta et al., ${ }^{1}$ who used different cut-points for exposure categories. Because of methodological limitations of the published $\mathrm{TiO} 2$ cohorts $^{4}$ we cannot support Tomenson's statement that there is "considerable weight of evidence from 3 large cohorts of no exposure-response".

We agree that our results need to be confirmed using a different analytical approach. We propose to reanalyse the available European $\mathrm{TiO} 2$ worker data using $\mathrm{G}$ methods ${ }^{5}$ to assess a potential health worker survivor effect and provide an unbiased estimation of the dose-response relationship.

\section{References}

1. Boffetta P, Soutar A, Weiderpass E, et al. Historical cohort study of workers employed in the titanium dioxide production industry in Europe. Results of mortality follow-up. Final report. Stockholm, Sweden: Department of Medical Epidemiology, Karolinska Institute 2003:147.

2. Guseva Canu I, Gaillen-Guedy A, Wild P, et al. Lung cancer mortality in the French cohort of titanium dioxide workers: some aetiological insights. Occup Environ Med 2020;77(11):795-97. doi: 10.1136/oemed-2020-106522 [published Online First: 2020/08/02]

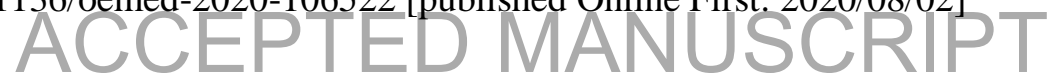


3. Axelson O. Confounding from smoking in occupational epidemiology. British journal of industrial medicine 1989;46(8):505-07. doi: 10.1136/oem.46.8.505

4. Guseva Canu I, Fraize-Frontier S, Michel C, et al. Weight of epidemiological evidence for titanium dioxide risk assessment: current state and further needs. J Expo Sci Environ Epidemiol 2020;30:430-35. doi: 10.1038/s41370-019-0161-2 [published Online First: 2019/08/20]

5. Naimi AI, Cole SR, Kennedy EH. An introduction to g methods. Int J Epidemiol 2017;46(2):756-62. doi: 10.1093/ije/dyw323 